form of localized basal meningitis. The disease, however, was not fatal. Dr. Lockhart Gibson saw many of these cases in Brisbane, and found in most of the patients referred to him that the most prominent signs were double optic neuritis and paresis of one external rectus-hence the name "ocular neuritis" he gives to the condition. His thoughts were directed to lead as a possible cause, first by the fact that coincident with the admission of the eye cases many cases of chronic lead poisoning were received, and, secondly, one patient showed, in addition to the eye symptoms, wrist drop. In others traces of lead were found in the urine. He at first thought that the source of contamination was to be sought in tank water, but eventually satisfied himself that it was due to the lead used in painting the rails of the verandahs of the houses where the patients lived. The paint, as it were, had weathered and was within easy reach of the children who invariably sucked their fingers or bit their nails, and in that way conveyed the poison into their systems. In the pamphlet under notice Gibson reprints nine of the more important contributions he has made to the subject, and many will be grateful to him for doing so. Incidentally the collection shows how large a part the author took in solving the mystery of the aetiology of the disease.

S.S.

\title{
CORRESPONDENCE
}

\section{THE BOWMAN LIBRARY}

To the Editor of The. British Journal of Ophthalmology

SiR,-You were good enough to publish a letter from me last year in Volume VI, p. 381, on the missing numbers of some periodicals in the library. Will you allow me space in which to report progress? The following journals have been brought up to date by the inclusion of missing parts :-

Klinische Monatsblätter für Augenheilkunde (1 part).

Archives d'Ophtalmologie (1 part).

The Ophthalmoscope (1 volume).

R. L. O. H. Reports (1 volume and 1 part).

Archivos de Oftalmologia Hispano-Americanos (2 parts).

The management of the American Journal of Ophthalmology has sent us the first five volumes of that journal, viz., 1918-1922, together with Vols. XVII and XVIII of Ophthalmic Literature; one of these parts was the last in stock. I am sure that English Ophthalmologists will appreciate this kindness on the part of the 
American Journal. A set of the Beitrage zur Augenheilkunde from Vol. I has been purchased by the Royal Society of Medicine, which, with the few parts of this journal which we already possessed, will give us a complete run of this journal to the end of the year 1917 .

Archives für Ophthalmologie (von Graefe) sent four volumes in exchange for Vol. XLII of the Transactions of the Ophthalmological Society of the United Kingdom.

I should like to express my gratitude to the many friends of the Bowman Library who have aided me in bringing the Library as much up to date as is possible at the present time.

\section{Yours faithfully,}

R. R. JAMES (Hon. Librarian).

\section{OPHTHALMOMYIASIS}

To the Editor of The British JoúRnal of Ophthalmologi

SIR,--Respecting the article on "Ophthalmomyiasis" by Dr. Ticho in the April number of the British Journal, of OphthaLMOLOGY, the following references are of interest :-

Wahba: Bulletin of the Ophthalmological Society of Egypt, 1915.

Barsoum : Bulletin of the Ophthalmological Society of Egypt, 1917.

Oulton: Bulletin of the Ophthalmological Society of Egypt, 1917.

Since 1916, 32 cases of external ophthalmomyiasis have been reported from various ophthalmic hospitals in Egypt and recorded in the annual reports of the Ophthalmic Section of the Department of Public Health. Most of the larvae from these cases have been examined and cultivated by the Egyptian Government entomologists Dr. Gough or Dr. Mangan and identified as wohlfahrtia magnifica schiner, or as cordylobia anthropophaga.

The great interest in Dr. Ticho's cases lies in the fact that they occurred quite suddenly as the result of intrusion into the conjunctival sac of viviparous larvae by diptera. Such a case was reported by Saleh (Bulletin of the Ophthalmological Society of Egypt, 1917). In the other cases seen in Egypt, the larvae were found in the orbital tissues. The wohlfahrtia is viviparous but not the cordylobia.

I am, Sir, Yours faithfully,

CaIro, April 17, 1923.

A. F. MacCallan. 